\title{
Environmental Quality, Corruption and Industry Growth: The Global Perspective
}

\author{
Jakość środowiska, korupcja i rozwój przemysłu: \\ perspektywa globalna
}

\author{
Min Cui ${ }^{\star}$, Jun-Sheng Wang*, Chun-Ping Chang ${ }^{\star *}$ \\ *Department of Economics, Xi'an University of Finance and Economics, \\ Xi'an, Shaanxi, China \\ **Corresponding author, Shih Chien University, Kaohsiung, Taiwan \\ E-mail (Corresponding Author): cpchang@g2.usc.edu.tw, \\ ORCID: 0000-0003-1782-4551
}

\begin{abstract}
This paper investigates the causal relationship between environmental quality and corruption for 129 countries, using the panel cointegration and panel-based error correction models for the period 2002-2015. In the paper, we use EPI, EHI, and EVI to represent environmental quality, which are more reasonable and comprehensive. We further take industry growth into consideration and investigate its impact on environmental quality. Our results corroborate that there exists a long-term equilibrium cointegrated relationship among the variables, both of corruption and industry growth have a negative effect on environmental quality and the corruption can seriously decrease environmental quality in the long term, while industry growth weakens environmental quality no matter in the short or long run.
\end{abstract}

Key words: environmental quality, corruption, industry growth, panel cointegration, causality

\section{Streszczenie}

W artykule zbadano związek przyczynowy między jakością środowiska a korupcją w 129 krajach, wykorzystując modele kointegracji panelowej i panelowej korekcji błędów za lata 2002-2015. W pracy używamy EPI, EHI i EVI do wyznaczania jakości środowiska, które wydają się najbardziej sensowne i wszechstronne. Ponadto bierzemy pod uwagę rozwój branży i badamy jego wpływ na jakość środowiska. Nasze wyniki potwierdzają, że istnieje długoterminowa stabilna skointegorowana relacja pomiędzy zmiennymi, zarówno korupcja, jak i rozwój przemysłu mają negatywny wpływ na jakość środowiska, a korupcja może poważnie obniżyć jakość środowiska w dłuższej perspektywie, podczas gdy wzrost przemysłu osłabia jakość środowiska zarówno w krótkim, jak i długim okresie.

Słowa kluczowe: jakość środowiska, korupcja, wzrost gospodarczy, kointegracja panelowa, przyczynowość

\section{Introduction}

With the current rapid development of the global economy, the destruction of the environment following it due to global warming, worsening air quality, and various other problems has become more serious. Therefore, a better understanding of the relationship between economic growth and environmental quality is of great interest in many countries, with sustainable development representing one of the most important policy goals. Evidence suggests that corruption is one of the major causes of environmental degradation in a country, especially in developing economies, as the cases of corruption in the environmental area represent a disproportionately significant part of all corruption cases across countries. In this paper, we test the relationship among corruption, industry growth and environmental quality via the panel cointegration approach. Our study contributes to the literature in several aspects. First, we use Environmental Performance Index (EPI), Environmental Health Index (EHI), and Ecosystem Vitality 
Index (EVI) to represent environmental quality, as they can reveal the effect of a country on the environment in terms of air, soil, and water, which are more reasonable and comprehensive. This is the main contribution to this study. Second, as to how a government would act when facing the conflict between economic growth and environmental protection, empirical studies tend to focus on the direct effect of per capita GDP growth on $\mathrm{CO}_{2}$ emissions, rarely taking industry growth into consideration. Here, we investigate the impact of industry growth on environmental quality in the long term and short run. Third, based on the conclusion, the paper provides specific suggestions to policymakers to promote environmental quality.

Moreover, before the empirical test between corruption and environmental quality, the paper give several cases to explain the negative impact of the corruption on environmental quality in different countries, which is another contribution to this paper. For example, in Indonesia, illegal mining and deforestation are protected by the corrupt government officials; In South Korea, due to an integrated chain of corruption and fraud, ten nuclear units have been shut down; In the Malaysian state of Sabah, water bureau corruption cause the remote areas can't get clean tap water quickly; In Africa, mineral resources are so rich that the rent-seeking and corruption by the government are quite serious; In Japan, the corruption lead to the Fukushima first nuclear power plant accidents; In the Asia Pacific region, environmental crime is a serious problem with consequences not only for environmental degradation, but also for good governance, security, and the legitimacy of legal institutions (Elliott, 2007); All these cases shows that greater corruptibility of policy makers reduces environment policy stringency, and leads to more polluting firms entering the market, thus seriously destroying the environment of these countries (the detail of cases can be seen in table 1).

Our empirical results offer the following implications. First, the results of the panel unit root test provide strong evidence that all variables are stationary. Second, according to Pedroni's panel cointegration tests results, the 129 countries' environmental quality have a long-run cointegration relationship with corruption, and industry growth. Third, the FMOLS estimations present that corruption and industry growth have a negative effect on environment quality in full samples case. Furthermore, the VECM estimation indicate that in the long run, causalities running from corruption and industry growth to environment quality in the 129 countries have a negative effect. In the short run, the corruption doesn't have a significant impact on environment quality, but industry growth does have. Our study offers policy implication that corruption may not impact the environment quality in a short period, but can decrease environment quality in a long-term, while industry value can weaken the environment quality no matter in the short run or the long run.

This paper consists of 5 sections. Section 2 reviews the literature. Section 3 introduces a brief presentation of the panel cointegration test. Section 4 discusses the empirical findings. Section 5 summarizes the main conclusions and gives some suggestions.

\section{Literature overview}

Since corruption is a global phenomenon that affects environmental quality in a country, it has attracted the interest of many economists to investigate the relationship between environment and corruption. Researchers' attention has concentrated primarily on the effects of corruption on the level of income. One related theoretical work is that of Alexandra (2010) who investigates how corruption influences the income level at the turning point of the relationship between sulfur emissions and income. That study finds that the higher a country's level of corruption is, the higher is per capita income at the turning point. Faiz et al. (2012) investigate the presence of a regional Environmental Kuznets Curve in selected South Asian countries. The fixed effect results indicate that corruption does affect the environment in such a manner that it delays the turning point in EKC. Zhang et al. (2016) studied the effect of corruption on $\mathrm{CO}_{2}$ emissions in APEC countries. The results show that there exists an inverted U-shaped EKC between corruption and $\mathrm{CO}_{2}$ emissions in APEC, per capita GDP at the turning point of the EKC may increase when $\mathrm{CO}_{2}$ emissions increase. Ole and Marina (2018) estimate the potentially moderating effects of democracy, corruption, and civil society activity on $\mathrm{CO}_{2}$ emission. They find that the per capita $\mathrm{CO}_{2}$ elasticity of GDP becomes non-monotonic and diminishes as GDP per capita increases in countries with democratic non-corrupt governments and high civil society participation.

Some economics literature has focused on the effects of corruption on energy policy, shadow economy, and environmental regulation. Fredriksson and Herman (2004) investigate how the corruptibility of policy makers affect the determination of energy policy in industrialized countries. Their research shows that greater corruptibility of policy makers reduces energy policy stringency, and greater lobby group coordination costs result in a more stringent energy policy. Amit et al. (2012) study how the shadow economy affects pollution and how this effect depends on corruption levels in public administration. The finding predicts that controlling the levels of corruption can limit the effect of the shadow economy on pollution. Biswas and Thum (2017) study the environmental standards when market entry is endogenous and firms can circumvent regulation by bribery. The result shows that corruption changes the tradeoff in environmental policy and leads more pol- 
Table 1. Cases of corruption and their effect on environment regulation and quality, authors' own study

\begin{tabular}{|c|c|}
\hline Case & Content \\
\hline $\begin{array}{l}\text { Gold rush in } \\
\text { Indonesia }\end{array}$ & $\begin{array}{l}\text { In Indonesia, gold ore can be processed into gold bullion; when gold is melted by mercury, the mercury } \\
\text { leaches into the soil, rivers, fishponds, and rice fields, worsening the environment seriously. Indonesia } \\
\text { government officials prohibit industries from using mercury in gold mining, but in some small firms, the } \\
\text { use of mercury is not completely banned. Many investors in illegal mining are from the capital of Jakarta, } \\
\text { and corrupt government officials, soldiers, and policemen provide protection for such activity. A local en- } \\
\text { vironmental protection organization said that the Indonesian army and policemen directly participate in } \\
\text { gold mining in some regions. }\end{array}$ \\
\hline $\begin{array}{l}\text { Deforesta- } \\
\text { tion in Indo- } \\
\text { nesia }\end{array}$ & $\begin{array}{l}\text { According to BBC news, lost forests in Indonesia in the past } 12 \text { years cover about } 50,000 \text { square kilome- } \\
\text { ters. The aim of such deforestation in Indonesia is to make use of the land for palm oil plantations and } \\
\text { farmland construction. Researchers at University of Maryland show that deforestation is the cause of } \\
\text { greenhouse gas increasing, which has severely devastated Indonesia's biodiversity. In } 2011 \text {, the Indonesia } \\
\text { government delayed the date of the reclamation permit issuance, aimed at slowing the rate of deforesta- } \\
\text { tion. However, according BBC journalist Karishma Vaswani's report, environmentalists show that corrupt } \\
\text { politicians began to sell vast reaches of the rainforest for high profits soon after the policy, which in turn } \\
\text { led to more forest lost in Indonesia. }\end{array}$ \\
\hline $\begin{array}{l}\text { Corruption } \\
\text { of nuclear } \\
\text { power in } \\
\text { South Korea }\end{array}$ & $\begin{array}{l}\text { In May } 2013 \text {, ten nuclear units have been shut down, caused by using disqualified products that lead to } \\
\text { frequent malfunctions. Because of such accidents, South Korea faced a national power supply shortage, } \\
\text { which triggered large-scale public discontent who worried about a nuclear crisis. An investigation by the } \\
\text { inspection department showed that in the process of nuclear power parts procurement, there was an inte- } \\
\text { grated chain of corruption and fraud, due to falsified product test reports made by parts supplier, parts in- } \\
\text { spection organizations, and an auditing organization of the parts inspection reports. }\end{array}$ \\
\hline $\begin{array}{l}\text { Water bu- } \\
\text { reau corrup- } \\
\text { tion in the } \\
\text { Malaysian } \\
\text { state of Sa- } \\
\quad \text { bah }\end{array}$ & $\begin{array}{l}\text { The Keningau water supply plan of Sabah's dream project spent money lavishly on the construction of a } \\
\text { geocentric gravitational water supply system. The aim of this plan is to transport clean tap water to vil- } \\
\text { lages. If } 60 \% \text { of the project costs had not been corrupted and stolen by governing classes, these expenses } \\
\text { could have supported } 8000 \text { projects. If there were no corruption and kleptocracy, then even people living } \\
\text { in remote regions could have gotten clean water in the } 1990 \text { s rather than in } 2016 \text {. However, because of } \\
\text { corruption in the Sabah water bureau, the remote areas in the Sabah state can only expect to get clean tap } \\
\text { water in } 2050 \text {. }\end{array}$ \\
\hline $\begin{array}{l}\text { Corruption } \\
\text { in Africa's } \\
\text { mineral re- } \\
\text { source sector }\end{array}$ & $\begin{array}{l}\text { Africa's mineral resources are so rich that the rent-seeking and corruption by the government are quite } \\
\text { serious. The rent of many African mineral resources accounts for a large proportion of the continent's } \\
\text { GDP, which easily results in rent-seeking behavior and serious corruption. Taking Nigeria as an example, } \\
\text { the mineral resources rent accounts for more than } 20 \% \text { of GDP. According to the Corruption Perceptions } \\
\text { Index released by Transparency International in } 2013 \text {, Nigeria's index is } 25 \text {, or } 144^{\text {th }} \text { among } 175 \text { countries } \\
\text { in the world. Although the Nigeria government has taken some measures to attack corruption, such as in- } \\
\text { stitutional reform on crimes related to corruption, the progress is still slow. }\end{array}$ \\
\hline $\begin{array}{c}\text { Nuclear } \\
\text { power plant } \\
\text { corruption in } \\
\text { Japan }\end{array}$ & $\begin{array}{l}\text { The causes of the Fukushima first nuclear power plant accidents are due to hesitation by high-level } \\
\text { TEPCO officials between protection of the reactor and abandoning it. TEPCO concealed failures and hid- } \\
\text { den dangers of nuclear power plant accidents to the Fukushima Prefecture and the central government. } \\
\text { The issues of Japan's nuclear safety cannot be solved by the rule of law, for there is a large number of } \\
\text { subsidiaries and peripheral groups in TEPCO. There already has been a large number of illegal behaviors } \\
\text { at TEPCO; most of the test and maintenance business in TEPCO are outsourced to its subsidiaries, and the } \\
\text { subsidiaries then outsource these businesses to smaller companies. TEPCO once forced the contractors to } \\
\text { forge hundreds of thousands of test data. Some denouncements by TEPCO staff or contractors have been } \\
\text { clamped down by the ministry of international trade and industry (MITI), the Security Bureau and other } \\
\text { departments. }\end{array}$ \\
\hline $\begin{array}{l}\text { Environmen- } \\
\text { tal crime and } \\
\text { corruption in } \\
\text { the Asia Pa- } \\
\text { cific Region }\end{array}$ & $\begin{array}{l}\text { In the Asia Pacific region, environmental crime is a serious problem with consequences not only for envi- } \\
\text { ronmental degradation and sustainable development, but also for good governance, security, and the legit- } \\
\text { imacy of legal institutions (Elliott, 2007). Aside from being a source of private gain for ruling elites, ille- } \\
\text { gal environmental activities also create a shadow economy (Elliot, 2011). For instance, in Indonesia, stud- } \\
\text { ies have shown that all forms of environmental crime resulted in losses to the Indonesian treasury of more } \\
\text { than US } \$ 8 \text { billion in } 2003 \text {. In the forestry sector, illegal logging has resulted in losses in revenue of about } \\
\text { US } \$ 3 \text { billion. As with other forms of transnational crime, such as narcotics and arms, bribery, and other } \\
\text { forms of corruption associated with environmental crime undermine good governance, corroding state in- } \\
\text { stitutions, and the rule of law (Elliott, 2011). }\end{array}$ \\
\hline $\begin{array}{l}\text { Illegal trade } \\
\text { in ozone de- } \\
\text { pleting sub- } \\
\text { stances }\end{array}$ & $\begin{array}{l}\text { Recent seizures show that ODS has increased sharply in developing countries, as the phase-out of ODS } \\
\text { commences (UNEP, website). Illegal trade in ODS has a negative impact on good governance, depriving } \\
\text { governments and legitimate industry of revenue and opening up opportunities for corrupt behavior. Based } \\
\text { on reports and recent seizures, its illegal trade in the Asia Pacific region is widespread and substantial and } \\
\text { has increased dramatically as the phase-out takes hold (UNEP, 2007). Bangladesh, China, South Korea, } \\
\text { India, Indonesia, Iran, Malaysia, Pakistan, Philippines, Sri Lanka, North Korea, Thailand, and Vietnam } \\
\text { are among the countries in the region that still have high consumption of CFCs (UNEP, 2007), making } \\
\text { such a market a highly profitable one. Due to the complexities surrounding the movement of illegal ODS, } \\
\text { as well as the nature of ODS chemicals, the identification of illegal material is extremely difficult. This } \\
\text { makes it much easier for smugglers to deceive a customs officer or ozone agent who is not well informed } \\
\text { without having to rely on corrupt practices (Toepfer, 2001). }\end{array}$ \\
\hline
\end{tabular}




\begin{tabular}{|c|l|}
\hline Case & Content \\
\hline & $\begin{array}{l}\text { Brazil's sprawling corruption scandal has implicated several mega-dams in the Amazon. One of them, } \\
\text { Belo Monte, would displace at least 20,000 people and extinguish some of the world's most diverse habi- } \\
\text { The hidden } \\
\text { tats, in some areas flooding and in others drying up hundreds of square miles of rain forest and croplands, } \\
\text { according to studies by International Rivers and others. It would produce more greenhouse gases than an }\end{array}$ \\
$\begin{array}{c}\text { vironmental } \\
\text { devastation }\end{array}$ & $\begin{array}{l}\text { equivalent fossil fuel plant for at least 20 years. One executive in the construction consortium was sen- } \\
\text { tenced to a 19-year prison term for corruption and money laundering, and the consortium is under investi- } \\
\text { gation for allegedly paying millions of US dollars in bribes to Brazil's beleaguered then-ruling party to } \\
\text { secure the concession (www.washingtonpost.com). }\end{array}$ \\
\hline
\end{tabular}

luting firms to enter the market. Still others analyze the influence of corruption from the perspective of resource curse and rent-seeking. Infante and Smirnova (2016) shows that a more stringent rule of law contributes to the achievement of the second-best allocation with less resource drainage caused by the rent-seeking activities. Boutilier (2017) derives local-level predictions from the macro-level literature and checks their accuracy in the case of a gold mine. The study indicates that a mining company's policies temporarily restrained rent-seeking, but both returned as closure neared and the company reduced its presence.

With rapid development of the economy, countries are experiencing a high speed economic development which may exert great pressure on the environment. Therefore, there is an ever-growing body of literature probing the relationship between economic development and environmental quality. Weibin Lin et al. (2011) uses a large household survey in China to measure the environmental and energy performance. The research propose a Green GDP in view of energy intensity and pollution intensity, which views economic growth and environmental sustainability as compatible. Chaabouni and Saidi (2017) investigated the relationship between $\mathrm{CO}_{2}$ emissions and GDP growth. The results indicate that there is a unidirectional causality from $\mathrm{CO}_{2}$ emissions to health spending, except low income group countries. Drews et al. (2018) examine public perceptions relevant to the growth debate by using data from a large number of representative surveys conducted in Europe and the US. The finding shows that a relative majority of respondents seem to believe that economic growth and environmental protection are compatible.

\section{Econometric methodology and model}

To study the panel cointegrated relationships among corruption, industry growth, and environmental quality, we adopt the panel cointegration test proposed by Pedroni (2004), which follows the fixed effect panel model:

$y_{i t}=\alpha_{i}+\beta_{1 i} x_{1 i, t}+\beta_{2 i} x_{2 i, t}+u_{i t, \quad} \quad i=1, \cdots, N, \quad t=1, \cdots, T$,

where $y_{i t}$ represents the dependent variable to measure environmental quality. Here, we use EPI (Environmental Performance Index), EVI (Ecosystem Vitality Index), and EHI (Environmental Health Index) to respectively measure environmental quality, $x_{1 i, t}$ denotes CCE to measure corruption, while $x_{2 i, t}$ represents IVA to measure industry growth.

The EPI, EVI, and EHI variables have the dimensions $(N \times T) \times 1$ and $(N \times T) \times M$, where $N$ represents the number of sample countries, $T$ is the observation period, $M$ reflects the regression variables, and $u_{i t}$ is the residual. The parameter $\alpha_{i}$ refers to the country-specific fixed effects. Heterogeneity exists within different economy's growth rates, which is the same as CCE and IVA in those cross-country differences also presenting important econometric problems.

we next estimate the cointegrated vectors. The process $u_{i t}$ in equation (1) can be written as:

$u_{i t}=\sum_{j=-\infty}^{\infty} \varphi_{i j} \varepsilon_{i t+j}+v_{i t}$,

where $v_{i t}$ is stationary with zero mean, $\varphi_{\text {it }}$ is smaller than infinity, and $v_{i t}$ and $\varepsilon_{i t}$ are uncorrelated contemporaneously with all lags and leads. We then adopt the FMOLS estimator that uses the past and future values of independent variables $x_{i t}$ as additional regressors. The FMOLS is an approach studied by Phillips and Hansen (1990) to investigate the bi-directional estimates between the selected variables. We now substitute equation (2) into equation (1) to get:

$y_{i t}=\alpha_{i}+\beta_{1 i} x_{1 i, t}+\beta_{2 i} x_{2 i, t}+\sum_{j=-q}^{q} \varphi_{i j} \Delta x_{i t+j}+\dot{v}_{i t}$,

where $\dot{v}_{i t}=v_{i t}+\sum_{|j|>q} \varphi_{i j} \varepsilon_{i t+j}$

Therefore, we obtain the estimator's FMOLS by running the following regression:

$y_{i t}=\alpha_{i}+\beta_{1 i} x_{1 i, t}+\beta_{2 i} x_{2 i, t}+\sum_{j=-q}^{q} \varphi_{i j} \Delta x_{i t+j}+\dot{v}_{i t}$

Hence, in the empirical model we would like to introduce $y_{i t}$ as EPI, EHI, and EVI, as well as $x_{i t}$ as CCE and IVA.

\section{Empirical results}

\subsection{Results of panel unit root and panel cointegra- tion}

The panel unit root test results in Table 2 indicate stationary behavior in all variables' first-differences at the 5\% significance level and follow the $I(1)$ process. Table 3 exhibits Pedroni's panel cointegration of the basic model. In the tables, no matter the dependent variable is EPI EVI or EHI, except for panel variance, panel, and group $\rho$ statistics, all other statistics reject the null hypothesis of no significant cointegration. According to these tests results, we 
Table 2. Panel unit root tests

\begin{tabular}{|c|c|c|}
\hline & LLC & ADF \\
\hline$\Delta E P I$ & $-46.55(0.000)^{* *}$ & $120.28(0.000)^{* *}$ \\
\hline$\Delta E V I$ & $-47.25(0.000)^{* *}$ & $109.32(0.000)^{* *}$ \\
\hline$\Delta E H I$ & $-89.29(0.000)^{* *}$ & $124.14(0.000)^{* *}$ \\
\hline$\Delta C C E$ & $-64.32(0.000)^{* *}$ & $122.52(0.000)^{* *}$ \\
\hline$\Delta I V A$ & $-41.04(0.000)^{* *}$ & $101.63(0.000)^{* *}$ \\
\hline
\end{tabular}

Notes: LLC and ADF tests are under the null of without a unit root. $\Delta$ denotes first differences. All variables are in natural logarithms. ** indicates statistical significance at the $5 \%$ level. Values in brackets are the probability value.

Table 3. Pedroni's panel cointegration tests - full sample

\begin{tabular}{|c|c|}
\hline \multicolumn{2}{|c|}{ Independent variables: CCE and IVA } \\
\hline panel v-stat & -3.98 \\
\hline panel $\rho$-stat & 1.85 \\
\hline panel pp-stat & $-17.42^{* *}$ \\
\hline panel ADF-stat & $-15.30^{* *}$ \\
\hline group $\rho$-stat & 6.33 \\
\hline group pp-stat & $-18.02^{* *}$ \\
\hline group ADF-stat Independent variables: CCE and IVA & $-14.18^{* *}$ \\
\hline \multicolumn{1}{|c|}{} \\
\hline panel v-stat & -4.41 \\
\hline panel $\rho$-stat & 1.89 \\
\hline panel pp-stat & $-18.01^{* *}$ \\
\hline panel ADF-stat & $-15.10^{* *}$ \\
\hline group $\rho$-stat & 6.47 \\
\hline group pp-stat & $-18.35^{* *}$ \\
\hline group ADF-stat & $-14.35^{* *}$ \\
\hline panel v-stat & \\
\hline panel $\rho$-stat & -1.18 \\
\hline panel pp-stat & 4.67 \\
\hline group $\rho$-stat & $-7.04^{* *}$ \\
\hline group pp-stat & $-5.68^{* *}$ \\
\hline group ADF-stat & 8.85 \\
\hline
\end{tabular}

Notes: Statistics are asymptotically distributed as normal. The variance ratio test is right-sided, while the others are leftsided. $* *$ and $*$ denote rejecting the null of no cointegration at the $5 \%$ and $10 \%$ significance levels.

believe that the 129 countries EPI, EVI, and EHI have a long-run cointegration relationship with CCE and IVA.

\subsection{Results of panel FMOLS estimation}

We next adopt the panel FMOLS estimation method offered by Kao and Chiang (2000) to calculate the individual and panel estimators. In Table 4, when EPI is considered as the dependent variable, the coefficients in the full sample of CCE and IVA are statistically significant at the 5\% level, the effects are negative, and the panel estimators are -3.25 and -1.53 , respectively. In the sample countries, more than half of their CCE has a negative impact on EPI. For the IVA, it also has a negative impact on EPI. On a per country basis, except for Cuba, Dem. Rep. Congo, Egypt, Georgia, Ghana, Haiti, Myanmar, Nicaragua, Niger, Panama, Serbia, Sierra Leone,
Tanzania, Turkey, and Turkmenistan, whose statistical significances are at the $5 \%$ level, and the impact are positive, the other countries all have a negative effect on EPI.

When EVI is considered as the dependent variable, the coefficients in the full sample of CCE are statistically significant at the 5\% level, the effects are negative, and the panel estimator is -3.77 . On an individual country basis, 69 countries' CCE has a negative effect on EVI, and about $36 \%$ of them have statistical significance at the $5 \%$ level. The coefficients of IVA also have a negative impact on EVI where statistical significance is at the $5 \%$ level, and the panel estimator is -2.04 . On a per country basis, 89 countries' IVA has a negative effect on EVI, and more than half of them have coefficients statistically significant at the $5 \%$ level. When we change the dependent variable to EHI, the panel estimators of CCE 
Table 4. FMOL estimates: EPI, CCE, and IVA - full sample (dependent variable is EPI)

\begin{tabular}{|c|c|c|c|c|c|}
\hline Country & $\mathrm{CCE}$ & IVA & Country & CCE & IVA \\
\hline Albania & $51.38^{*}$ & -3.14 & Estonia & $65.20^{* *}$ & -1.61 \\
\hline Algeria & 28.87 & $-1.43^{* *}$ & Ethiopia & $29.10^{* *}$ & 0.01 \\
\hline Argentina & $-134.31^{* *}$ & $-2.97^{* *}$ & Finland & $36.67^{* *}$ & $-3.23^{* * *}$ \\
\hline Armenia & $49.82^{*}$ & $-1.20^{* *}$ & France & $-67.79^{* *}$ & $-6.54^{* *}$ \\
\hline Australia & $-28.79^{* *}$ & 0.88 & Gabon & 32.86 & -0.09 \\
\hline Austria & -8.68 & -1.36 & Gambia & -19.41 & -4.16 \\
\hline Azerbaijan & 89.24 & 0.23 & Georgia & $19.24^{* *}$ & $1.36^{* *}$ \\
\hline Bangladesh & 10.06 & 3.52 & Germany & -2.08 & 1.28 \\
\hline Belarus & $43.02^{* *}$ & 0.21 & Ghana & $59.80^{*}$ & $3.67^{* * *}$ \\
\hline Belgium & 16.02 & -3.08 & Greece & $-38.82^{* * *}$ & 1.61 \\
\hline Benin & -6.78 & -1.09 & Guatemala & -0.24 & -2.94 \\
\hline Bolivia & -9.70 & 0.28 & Guinea & -2.07 & $-4.56^{* *}$ \\
\hline Bosnia and Herzegovina & 23.87 & 2.29 & Haiti & -25.52 & $1.24^{* * *}$ \\
\hline Botswana & $-55.07^{*}$ & $-1.10^{*}$ & Honduras & 5.57 & $-10.51^{\text {** }}$ \\
\hline Brazil & -0.21 & $-7.74^{* *}$ & Hungary & $-28.69^{* *}$ & 1.16 \\
\hline Bulgaria & $-66.73^{* * *}$ & $-5.73^{* *}$ & India & 3.20 & $-5.97^{* *}$ \\
\hline Cameroon & $-63.98^{* *}$ & $-3.73^{*}$ & Indonesia & $37.92^{* *}$ & $-2.31^{* *}$ \\
\hline Chad & $27.60^{*}$ & -0.10 & Iran & -3.88 & $-1.23^{* *}$ \\
\hline Chile & $15.55^{*}$ & $-1.38^{* *}$ & Iraq & 53.11 & $-1.30^{* * *}$ \\
\hline China & 33.29 & -2.88 & Ireland & -8.98 & -0.23 \\
\hline Colombia & -88.98 & -0.57 & Israel & 9.47 & $-6.63^{* *}$ \\
\hline Costa Rica & -10.40 & $-6.02^{* *}$ & Italy & -12.60 & -1.88 \\
\hline Croatia & $22.53^{* *}$ & $-11.12^{* *}$ & Jamaica & -17.16 & -3.35 \\
\hline Malaysia & $40.66^{* *}$ & $-2.11^{* *}$ & Serbia & $39.87^{* *}$ & $3.33^{* *}$ \\
\hline Mali & -19.40 & $-3.59^{* *}$ & Sierra Leone & $85.61^{* *}$ & $1.86^{* *}$ \\
\hline Malta & 18.99 & $-2.95^{* *}$ & Singapore & $-21.53^{* *}$ & -0.41 \\
\hline Mauritius & $-28.05^{* *}$ & $-2.85^{* *}$ & Slovakia & $-34.82^{* *}$ & -0.08 \\
\hline Mexico & $-44.78^{* *}$ & 0.49 & Slovenia & $-33.24^{* *}$ & $-1.45^{* *}$ \\
\hline Moldova & $-52.98^{*}$ & $-6.35^{* *}$ & South Africa & $-29.25^{* *}$ & $-4.86^{* *}$ \\
\hline Mongolia & 22.66 & 0.10 & Spain & -1.87 & $-1.16^{* *}$ \\
\hline Montenegro & -6.88 & $-6.41^{* *}$ & Sri Lanka & -39.13 & 0.72 \\
\hline Morocco & -7.99 & 5.69 & Sudan & $-11.01^{* * *}$ & $-0.66^{* * *}$ \\
\hline Mozambique & $-61.68^{* * *}$ & $-2.90^{* *}$ & Suriname & $-21.02^{* * *}$ & $-1.01^{* *}$ \\
\hline Myanmar & $25.17^{* *}$ & $0.27^{* *}$ & Sweden & 10.11 & $-3.42^{* *}$ \\
\hline Namibia & 96.98 & -3.98 & Tajikistan & -77.53 & $-2.21^{*}$ \\
\hline Nepal & 11.49 & $-4.39^{* *}$ & Tanzania & $-16.48^{* *}$ & $3.56^{* * *}$ \\
\hline Netherlands & 0.13 & $-2.49^{* *}$ & Thailand & $-45.20^{* *}$ & $-4.96^{* *}$ \\
\hline New Zealand & -49.38 & $-2.64^{* *}$ & Trinidad and Tobago & $-85.24^{* *}$ & -0.13 \\
\hline Nicaragua & -5.79 & $3.58^{* *}$ & Tunisia & 3.23 & -0.26 \\
\hline Niger & $17.64^{*}$ & $1.09^{* *}$ & Turkey & 5.37 & $3.41^{\text {*** }}$ \\
\hline Nigeria & -7.57 & $-1.35^{* *}$ & Turkmenistan & $51.10^{* *}$ & $0.59^{* * *}$ \\
\hline Norway & $29.94^{* *}$ & -0.26 & Uganda & $-85.62^{* *}$ & 0.44 \\
\hline Oman & $-30.92^{* * *}$ & -0.34 & Ukraine & -6.42 & $-3.03^{* *}$ \\
\hline Pakistan & -0.72 & -2.38 & United Arab Emirates & $-7.83^{* *}$ & -0.08 \\
\hline
\end{tabular}




\begin{tabular}{|c|c|c|c|c|c|}
\hline Country & CCE & IVA & Country & CCE & IVA \\
\hline Panama & -13.45 & $2.81^{* *}$ & United Kingdom & $58.42^{* *}$ & $-11.67^{* *}$ \\
\hline Papua New Guinea & $11.08^{* *}$ & $-0.56^{* *}$ & United States of America & -16.30 & -1.52 \\
\hline Cuba & $-123.31^{* *}$ & $9.28^{* *}$ & Japan & $25.39^{* *}$ & 1.11 \\
\hline Cyprus & $11.61^{* *}$ & $-1.70^{* *}$ & Jordan & -13.76 & 0.16 \\
\hline Czech Republic & $-17.73^{* *}$ & -0.52 & Kazakhstan & $79.18^{* *}$ & $-1.53^{* *}$ \\
\hline Dem. Rep. Congo & 31.19 & $1.13^{* *}$ & Kenya & $-115.23^{*}$ & -4.35 \\
\hline Denmark & $-29.76^{*}$ & $-2.98^{* *}$ & Latvia & -7.74 & $-17.41^{* * *}$ \\
\hline Dominica & -86.40 & -10.41 & Lebanon & $-30.98^{* *}$ & 2.38 \\
\hline Dominican Republic & -74.77 & -0.42 & Lithuania & $68.49^{* *}$ & -0.98 \\
\hline Ecuador & $46.69^{* *}$ & 0.45 & Luxembourg & 1.37 & $-0.66^{* *}$ \\
\hline Egypt & 5.70 & $1.63^{* *}$ & Madagascar & $-20.51^{* *}$ & 2.45 \\
\hline El Salvador & -65.58 & 3.47 & Malawi & -8.93 & $-2.45^{* *}$ \\
\hline Paraguay & -35.76 & $-5.34^{* *}$ & Senegal & 27.83 & -3.26 \\
\hline Peru & $-79.84^{* *}$ & -0.51 & Uruguay & $50.97^{* *}$ & 2.22 \\
\hline Philippines & $59.61^{* *}$ & $-5.67^{* *}$ & Uzbekistan & -13.21 & 0.98 \\
\hline Poland & $26.70^{* *}$ & 1.77 & Venezuela & $-54.17^{* *}$ & -0.34 \\
\hline Portugal & $-57.36^{* *}$ & $-2.07^{* *}$ & Viet Nam & $58.33^{* *}$ & $-1.04^{*}$ \\
\hline Qatar & -3.21 & $-0.05^{*}$ & Yemen & $-31.86^{* *}$ & 0.03 \\
\hline Romania & $124.48^{* * *}$ & -1.98 & Zambia & $165.34^{* * *}$ & $-4.33^{* * *}$ \\
\hline Russia & -0.21 & $-7.13^{* *}$ & Zimbabwe & $-70.21^{* *}$ & $-1.19^{* *}$ \\
\hline Saudi Arabia & $9.76^{* *}$ & -0.05 & Panel Group & $-3.25^{* *}$ & $-1.53^{* *}$ \\
\hline
\end{tabular}

Note: $* *$ and $*$ denote rejecting the null of no cointegration at the $5 \%$ and $10 \%$ levels, respectively.

reject the null of no cointegration at the $10 \%$ level, and the panel estimator is -1.37 . On an individual country basis, 70 countries' CCE have a negative effect on EHI. The panel estimators of IVA also reject the null of no cointegration at $10 \%$ level, and the panel estimator is -0.67 . On a per country basis, 74 countries' IVA has a negative effect on $\mathrm{EHI}^{1}$.

\subsection{Results of panel VECM estimation}

We next establish VECM, which uses the two-step procedure from Engle and Granger (1987) to estimate both short-run and long-run causalities among environmental quality, corruption, and industry growth. First, we estimate the long-run model like equations (5), (6), and (7) that can obtain the estimated residuals $\varepsilon_{i t}, \varepsilon_{i t}^{\prime}$, and $\varepsilon_{i t}^{\prime \prime}$, which are identified as the error correction term, country, and time fixed effects shown as $\alpha$ and $\delta$, respectively.

$$
\begin{aligned}
& E P I_{i t}=\alpha_{i}+\delta_{i} t+\beta_{1 i} C C E_{i t}+\beta_{2 i} I V A_{i t}+\varepsilon_{i t} \\
& E V I_{i t}=\alpha_{i}^{\prime}+\delta_{i}^{\prime} t+\beta_{1 i}^{\prime} C C E_{i t}+\beta_{2 i}^{\prime} I V A_{i t}+\varepsilon_{i t}^{\prime} \\
& E P I_{i t}=\alpha_{i}^{\prime \prime}+\delta_{i}^{\prime \prime} t+\beta_{1 i}^{\prime \prime} C C E_{i t}+\beta_{2 i}^{\prime \prime} I V A_{i t}+\varepsilon_{i t}^{\prime \prime}
\end{aligned}
$$

According to the previous findings, we next estimate Granger causality as:

\footnotetext{
${ }^{1}$ Due to the space limitation, here we mainly give the analysis Results when dependent variable change to EVI
}

$$
\begin{aligned}
\Delta E P I_{i t}= & \chi_{1 i}+\lambda_{1} E C M_{i t-1}+\sum_{p} \theta_{11 p} \Delta E P I_{i t-p}+\sum_{p} \theta_{12 p} \Delta C C E_{i t-p} \\
& +\sum_{p} \theta_{13 p} \Delta I V A_{i t-p}+u_{1 i t} \\
\Delta E V I_{i t}= & \chi_{2 i}+\lambda_{2} E C M_{i t-1}+\sum_{q} \theta_{21 q} \Delta E V I_{i t-q}+\sum_{q} \theta_{22 q} \Delta C C E_{i t-q} \\
& +\sum_{q} \theta_{23 q} \Delta I V A_{i t-q}+u_{2 i t} \\
\Delta E H I_{i t}= & \chi_{3 i}+\lambda_{3} E C M_{i t-1}+\sum_{k} \theta_{31 k} \Delta E H I_{i t-k}+\sum_{k} \theta_{32 k} \Delta C C E_{i t-k} \\
& +\sum_{k} \theta_{33 k} \Delta I V A_{i t-k}+u_{3 i t}
\end{aligned}
$$

Here, $t$ denotes the time period from 2002-2015, $i$ denotes the cross-sections that are 129 countries, $u_{1 i t}$, $u_{2 \text { it }}$ and $u_{3 i t}$ are error terms, ECM is the lagged error correction term, $p, q$, and $k$ are the lag lengths, and $x_{1 i}, x_{2 \mathrm{i}}$ and $x_{3 i}$ represent the fixed country effects. Based on the models, for short-run causality we can test $H_{0}: \theta_{12 p}=0$ and $\theta_{13 p}=0$ for all $p$ in equation (8), $\Theta_{22 q}=0$ and $\Theta_{23 q}=0$ for all $q$ in equation (9), or $\Theta_{32 q}$ $=0$ and $\Theta_{33 q}=0$ or all $k$ in equation (10). Additionally, the significance of $\lambda$ implies a long-run relationship in the process of cointegration and also that comovements with this path are permanent. For longrun causality, we can test $H_{0}: \lambda_{1}=0, \lambda_{2}=0$, or $\lambda_{3}=0$ in equations (8), (9), and (10), respectively.

and EHI, the reader who has the interest on the detail of the empirical results can get from author. 
Table 5. Panel causality test - full sample

\begin{tabular}{|c|c|c|c|c|c|c|c|}
\hline \multicolumn{8}{|c|}{ Source of causation (EPI, CCE, IVA) } \\
\hline \multirow{2}{*}{$\begin{array}{c}\text { Dependent } \\
\text { variable }\end{array}$} & \multicolumn{3}{|c|}{ Short run } & \multicolumn{4}{|c|}{ Long run } \\
\hline & $\triangle E P I$ & $\triangle C C E$ & $\triangle I V A$ & $\lambda$ & $\lambda / \triangle E P I$ & $\lambda / \triangle C C E$ & $\lambda / \triangle I V A$ \\
\hline$\triangle E P I$ & - & 0.48 & $4.02 * *$ & $-2.29 * *$ & - & $2.14 *$ & $4.54 * *$ \\
\hline \multicolumn{8}{|c|}{ Source of causation (EVI, CCE, IVA) } \\
\hline \multirow{2}{*}{$\begin{array}{c}\text { Dependent } \\
\text { variable }\end{array}$} & \multicolumn{3}{|c|}{ Short run } & \multicolumn{4}{|c|}{ Long run } \\
\hline & $\Delta E V I$ & $\triangle C C E$ & $\triangle I V A$ & $\lambda$ & $\lambda / \Delta E V I$ & $\lambda / \triangle C C E$ & $\lambda / \Delta I V A$ \\
\hline$\Delta E V I$ & - & 0.21 & $2.52 *$ & $-4.00 * *$ & - & $5.55 * *$ & $7.05^{* *}$ \\
\hline \multicolumn{8}{|c|}{ Source of causation (EHI, CCE, IVA) } \\
\hline \multirow{2}{*}{$\begin{array}{c}\text { Dependent } \\
\text { variable }\end{array}$} & \multicolumn{3}{|c|}{ Short run } & \multicolumn{4}{|c|}{ Long run } \\
\hline & $\Delta E H I$ & $\triangle C C E$ & $\triangle I V A$ & $\lambda$ & $\lambda / \Delta E H I$ & $\lambda / \triangle C C E$ & $\lambda / \triangle I V A$ \\
\hline$\triangle E H I$ & - & 1.32 & $4.71 * *$ & $-3.48 * *$ & - & $4.96 * *$ & $7.51 * *$ \\
\hline
\end{tabular}

Note: $* *$ and $*$ indicate statistical significance at the $5 \%$ and $10 \%$ levels, respectively.

As result shows in tables 5, when dependent is EPI, the test results present evidence that $\lambda$ exhibits longrun causality from both $\mathrm{CCE}$ and IVA to EPI at the $5 \%$ significant level, the effects are negative, and the panel estimator is -3.77 . Moreover, for short-run causality between EPI and CCE, we find that the EPI equation is insignificant. However, for short-run causality between EPI and IVA, we see that the EPI equation is significant at the $5 \%$ level and the effects are positive.

When dependent is EVI or EHI, the result indicates evidence that $\lambda$ exhibits long-run causality from both CCE and IVA to EVI and EHI at the 5\% significant level, the effects are negative, and the panel estimator are -4.00 and -3.48 , respectively. For short-run causality, when mentioning the causality between EVI and CCE, the EVI equation is insignificant. For short-run causality between EVI and IVA, the EVI equation is significant, the effects are positive, and the panel estimator is 2.52 . For short-run causality between EHI and CCE, the result shows that the EHI equation is insignificant. Short-run causality between EHI and IVA shows that the EHI equation is significant at the 5\% level, the effects are positive, and the panel estimator is 4.71 .

\section{Concluding remarks and policy suggestions}

This research checks the co-movement and causality among environmental quality, corruption, and industry growth, employing data of 129 countries from 2002-2015. Our results show a clear cointegration relationship among environmental quality, corruption, and industry growth, and the panel FMOLS estimations confirm that both corruption and industry growth have a negative effect on environmental quality. In accordance with our panel VECM estimation, the results indicate in the long run evidence exists for causalities running from corruption and industry growth to environmental quality in the 129 countries. These causalities have a negative effect, meaning that an increase in corruption and industry value leads to environmental degradation in the sample countries. In the short run, the test results show that corruption does not have a significant impact on environmental quality, but industry growth does have. The policy implication is that corruption may not impact the environmental quality over a short period, but can seriously decrease environmental quality in the long term, while industry growth can significantly weaken environmental quality no matter in the short run or the long run.

Corruption levels show little variation over time, and strategies to reduce them require political will, but there is still a long way to go. Here, we mention several strategies for the countries to cope with corruption and promote environmental quality. First, understanding the transmission channels through which corruption affects environmental quality is quite important. Once we are aware of the effects of corruption on these transmission channels, policy interventions in countries characterized by high levels of corruption can take these effects into account and deal with them (Lorenzo, 2008). Second, producing a double benefit on economic growth and under stringent environmental protection, such as the 2003 U.N. Convention Against Corruption, one of the outcomes of international efforts to tackle corruption has made a real effect on its implementation and other agreements that aim to deter corruption. Third, countries can tighten their environmental regulations. Countries where corruption is widespread need more stringent environmental regulation to reduce powerful lobbies on policymakers. It is necessary to tighten the rule of law to guarantee effective monitoring and enforcement of environmental standards, so that they can contribute to achieving secondbest allocation with less resource drainage (Infante and Smirnova, 2016).

For the contradiction between industry growth and environmental quality, it can be relieved or resolved by some effective measures. One way is to adopt a green industry in order to spur a new growth mode to achieve sustainable development worldwide. The basic principles of it are to minimize resources and 
emissions (Anityasari and Rachmat, 2015). The industries themselves should first establish an awareness of responsibility for their actions by assuming a fair and sustainable development attitude, such as introducing green products. Furthermore, corporations could implement a program of green industry through a governmental policy to improve effectiveness and efficiency. Another way is to use renewable energy. Renewable energy has a negative significant effect on $\mathrm{CO}_{2}$ emissions (Bekhet and Othman, 2018). Moreover, governments should institute strict regulations on the use of energy standards and encourage people to change their habits of energy consumption, by using clean and renewable energy.

\section{References}

1. ALEXANDRA L., 2010, Corruption and the environmental Kuznets Curve: Empirical evidence for sulfur, in: Ecological Economics, 69, p. 2191-2201.

2. ANUT K. B., MOHAMMAD R. F., MARCEL T., 2012, Pollution, shadow economy and corruption: Theory and evidence, in: Ecological Economics, 75, p. 114-125.

3. ANITYASARI M., RACHMAT A. N., 2015, Lesson Learnt from Top-down Selection of Medium Enterprises for Green Industry Pilot Project in Surabaya, in: Industrial Engineering and Service Science, 04, p. 54-61.

4. BISWAS A. K., THUM M., 2017, Corruption, environmental regulation and market entry, in: Environment \& Development Economics, 22, p. 66-83.

5. BOUTILIER R. G., 2017, Original article: Raiding the honey pot: The resource curse and weak institutions at the project level, in: The Extractive Industries and Society, 04, p. 310-320.

6. BEKHET H. A., OTHMAN N. S., 2018, The role of renewable energy to validate dynamic interaction between $\mathrm{CO} 2$ emissions and GDP toward sustainable development in Malaysia, in: Energy Economics, 72, p. 47-61.

7. CHERNI J. A., 2002, Economic Growth Versus the Environment : The Politics of Wealth, Health and Air Pollution, Palgrave Macmillan: Houndmills, Basingstoke, Hampshire.

8. CHAABOUNI S., SAIDI K., 2017, The dynamic links between carbon dioxide $\left(\mathrm{CO}_{2}\right)$ emissions, health spending and GDP growth: A case study for 51 countries, in: Environmental Research, 158, p. 137144.

9. CHAABOUNI S., SAIDI K., 2017, The dynamic links between carbon dioxide $\left(\mathrm{CO}_{2}\right)$ emissions, health spending and GDP growth: A case study for 51 countries, in: Environmental Research, 158, p. 137-144.

10. DREWS S., ANTAL M., VAN D. B., JEROEN C.J.M., 2018, Analysis: Challenges in Assessing Public Opinion on Economic Growth Versus Environment: Considering European and US Data, in: Ecological Economics, 146, p. 265-272.
11. ELLIOTT L., 2007, Transnational Environmental Crime in the Asia-Pacific: an "under secutized" security problem?, in: The Pacific Review, 20, p. 499522.

12. ELLIOTT L., 2011, Transnational Environmental Crime: Applying network theory to an investigation of illegal trade, criminal activity and law enforcement responses, Transnational Environmental Crime Project, Working paper, no 1.

13. ENGLE R. F., GRANGER C. W. G., 1987, Econometric forecasting: a brief survey of current and future techniques, in: Climate Change, 11, p. 117139.

14. FREDRIKSSON P. G., HERMAN R.J. V., ELBERT D., 2004, Corruption and energy efficiency in OECD countries: theory and evidence, in: Journal of Environmental Economics and Management, 47, p. 207231.

15. FAIZ R., MUHAMMAD N., FAIZA K., 2012, Nexus between corruption and regional Environmental Kuznets Curve: the case of South Asian countries., in: Environment, Development and Sustainability, 14, p. 827.

16. FRIEDL B., GETZNER M., 2003, Determinants of CO2 emissions in a small open economy, in: Ecol. Econ, 01, p. 133-148.

17. HUANG Y., LIU L., 2014, Fighting corruption: A long-standing challenge for environmental regulation in China, in: Environmental Development, 06, p. 1-3.

18. INFANTE D., SMIRNOVA J., 2016, Environmental Technology Choice in the Presence of Corruption and the Rule of Law Enforcement, in: Transformations in Business and Economics, 15, p. 214-224.

19. KAO C., CHIANG M. H., 2000, On the estimation and inference of a cointegrated regression in panel data, in: Adv Econometrics, 15, p. 179-222.

20. LORENZO P., 2008, Corruption, Development and the Environment, Vrige University.

21. NIU J., CHANG C. P., YANG X. Y.,WANG J. S., 2017, The long relationships between energy efficiency and environmental performance: Global evidence, in: Energy and Environment, 06, p. 1-19.

22. OLE M. L., MARINA P., 2018, Do Political Institutions Moderate the GDP-CO2 Relationship? in: Ecological Economics, 145, p. 441-450.

23. PEDRONI P., 2004, Panel cointegration: asymptotic and finite sample properties of fooled time series tests with an application to the PPP hypothesis, in: Econometric Theory, 20, p. 597-625.

24. PHILLIPS P. C. B., HANSEN B. E., 1990, Statistical inference in instrumental variables regression with the I (1) process, in: Rev Econ Dtud, 57, p. 99-125.

25. WEI B. L., BIN C., JIN Y. 2011, Temporal and Spatial Analysis of Integrated Energy and Environment Efficiency in China Based on a Green GDP Index, in: Energies, 9, p.1376-1390.

26. ZHANG Y. J., JIN Y. L., CHEVALLIER J., SHEN B., 2016, The effect of corruption on carbon dioxide emissions in APEC countries: A panel quantile regression analysis, in: Technological Forecasting \& Social Change, 112, p. 220-227. 
